\title{
Fe-Si-Al 系圧粉磁芯の磁気特性に及ぼす噴霧粉形状の影響
}

\author{
武本 聡 ${ }^{*}$, 斉藤貴伸 ${ }^{*}$

\section{Effects of Particle Shapes on Magnetic Properties of Compressed Cores with Fe-Si-Al Atomized Powders}

\author{
Satoshi Takemoto, and Takanobu Saito
}

\section{Synopsis}

Powder cores made with Fe-Si-Al alloys, Mo-permalloy and so on are widely used for smoothing and boost choke coils of switching regulators and DC-DC converters. High permeability at DC bias magnetic field is required to be high performance and miniaturization of these magnetic cores. In this study effects of particle shapes on magnetic properties of compressed powder cores with $\mathrm{Fe}$-Si-Al modified water-atomized powders were investigated. We concluded as follows.

(1) Initial permeability and DC bias characteristics continuously change with particle shapes. Cores with elliptical shaped (large aspect ratio) powders exhibited high initial permeability but inferior DC bias characteristics. While with spherical shaped (small aspect ratio) powders, initial permeability was relatively low, but the permeability at high DC bias magnetic field was higher than that of elliptical shaped powders.

(2) Differences of initial permeability with particle shapes can be explained by the differences of effective demagnetizing factors $N$ of the particles through the analysis using Ollendorf's equation. It is guessed that in case particles have large aspect ratios, they have small $N$, consequently initial permeability is high. Furthermore from the estimation of $N$, the core is magnetized connecting about four particles.

(3) Permeability depends on not only particle shape of powder but also relative density of core. Using of spherical shaped particles rather than elliptical and higher density result in both high initial permeability and excellent DC bias characteristics.

\section{1. 緒 言}

近年 , パーソナル・コンピュータ, ワード・プロセッ サ, ファクシミリなどの $0 \mathrm{~A}$ 機器の高機能化の要求が高 まっている．また，自動車においては直噴エンジン制御や 高輝度放電型のヘッドライトが普及し始めている．

これらの $0 \mathrm{~A}$ 機器や自動車の上述の制御用電源にはス イッチング電源や DC-DC コンバーターが欠かせないもの となっている.圧粉磁芯は軟磁性粉末に絶縁物を混合した 後，例えばトロイダル状にプレス成形したもので，これら の電源の平滑用チョークコイルや, 昇圧チョッパ用チョー クコイルの磁芯として多用されている．

圧粉磁芯用軟磁性粉末は光の成分として主にFe-Si-Al系 合金が用いられており，一般的にはインゴットを機械的に 粉砕した粉砕粉や噴霧粉を原料として用いることが多い.
筆者らは前報 ${ }^{1), 2)}$ で噴霧粉を用いた $\mathrm{Fe}-\mathrm{Si}-\mathrm{Al}$ 系圧粉磁芯に ついて報告し，噴霧方法による粉末粒子形状の違いによっ て, 磁芯の透磁率や抵抗率に違いが生じることを明らかに してきた.本研究では, 前報による粉末粒子形状が磁気特 性に大きく影響を及ぼしている事実に着目し，これをさら に詳細に定量的に議論するために噴霧粉の粒子形状を連 続的に変化させて初透磁率および直流重畳特性との関係 を明確にすることを目的とした.直流重畳特性とは,直流 バイアス磁界を印加させたときの透磁率の変化を指し ,ス イッチング電源のチョークコイルのような用途では, 磁芯 の性能を決定する重要な因子である .

\section{2 . 実験方法}

2.1 試験に用いた原料粉末 
Table 1. Chemical compositions of experimented Fe-Si-Al alloy powders (mass \%).

\begin{tabular}{c|c|c|c|c|c|c|c}
\hline $\mathrm{C}$ & $\mathrm{Si}$ & $\mathrm{P}, \mathrm{S}$ & $\mathrm{Mn}, \mathrm{Cu}, \mathrm{Ni}, \mathrm{Cr}$ & $\mathrm{Al}$ & $\mathrm{N}$ & $\mathrm{O}$ & $\mathrm{Fe}$ \\
\hline $\max .0 .020$ & $9.33 \sim 9.76$ & $\max .0 .004$ & $\max .0 .02$ & $5.44 \sim 5.85$ & $\max .0 .004$ & $0.09 \sim 0.20$ & balance \\
\hline
\end{tabular}

Table 2. Particle distributions of experimented Fe-Si-Al alloy powders.

\begin{tabular}{|c|c|c|c|c|c|c|}
\hline \multicolumn{6}{|c|}{ Particle size distribution (mass\%) (mesh) } & \multirow{2}{*}{$\begin{array}{c}\text { Mean diameter } \\
D_{50}(\mu \mathrm{m})\end{array}$} \\
\hline+100 & $\begin{array}{r}-100 \\
+145\end{array}$ & $\begin{array}{r}-145 \\
+200\end{array}$ & $\begin{array}{r}-200 \\
+250\end{array}$ & $\begin{array}{r}-250 \\
+350\end{array}$ & -350 & \\
\hline $0.02 \sim 0.08$ & $9.7 \sim 12.1$ & $19.4 \sim 24.3$ & $10.4 \sim 12.9$ & $15.1 \sim 19.1$ & $29.6 \sim 38.8$ & $50 \sim 60$ \\
\hline
\end{tabular}

本報告では改良型水噴霧により作製した噴霧粉を使用 した .改良型水噴霧とは従来の水噴霧の操業条件を制御す ることにより粉末の形状をコントロールできる噴霧法で ある.粒子形状を連続的に変化させた 5 種類の原料粉末を 用いた . 粉末粒径はいずれも -100 メッシュとし , 重量平 均粒径 $D_{50}$ は $50 \sim 60 \mu \mathrm{m}$ の間であった.成分は軟磁気特 性が最も良好とされている Fe-9.6 mass\%Si-5.4 mass\%Al に 近いものを用いた .試験に用いた原料粉末の成分および粒 度分布を Table 1, Table 2 に示す。

\section{2 粉末粒子形状の変化}

粉末の形状はアスペクト比 (=長軸/短軸) で表すことに し , アスペクト比は $1.3 \sim 1.8$ まで変化させた . アスペク 卜比は下で述べるような手順で作製した圧粉磁芯の縦断 面を樹脂に埋め込み，断面より 400 個以上の粉末をランダ ムに選び，長軸と短軸の長さを測定してアスペクト比を求 め, 平均值をとった . Fig.1 に代表的な 3 種類の圧粉磁芯 の断面観察写真を示す.観察面は磁芯の縦断面で , 図中の 左右の方向か磁路方向になるようにした . 粉末の長軸方向 は磁路方向に対して必ずしも平行ではなく角度を有して 分布しているが,粉末のアスペクト比を変化させてもこの 平均の角度は変化しなかった.このため, 本研究では粉末 のアスペクト比は単に独立粉末として測定し, 磁路方向に 対する考慮は行わなかった.粉末のアスペクト比が大きい 場合には長円形の粉末が多く見られ,アスペクト比が小さ くなるに従い粉末粒子形状は球形に近づいていることが 分かる.

\section{3 圧粉磁芯の作製}

まず,原料粉末にバインダーおよび粒子間の電気的絶縁 のためにシリコーン樹脂 ( 東レ・ダウコーニング・シリ コーン社製 SR-2400) を 1 mass\% 混合した . 乾燥後 , 潤滑 剂としてへガネス社製ケノルーブを 0.5 mass\% 混合してプ レス成形した . 成形は室温で $1080 \sim 1960 \mathrm{MPa}$ の圧力で 油圧プレス機を用いて行なった．磁芯のサイズは外径 28 $\mathrm{mm}$ 内径 $20 \mathrm{~mm}$ 高さ約 $5 \mathrm{~mm}$ のトロイダル状とした .成形

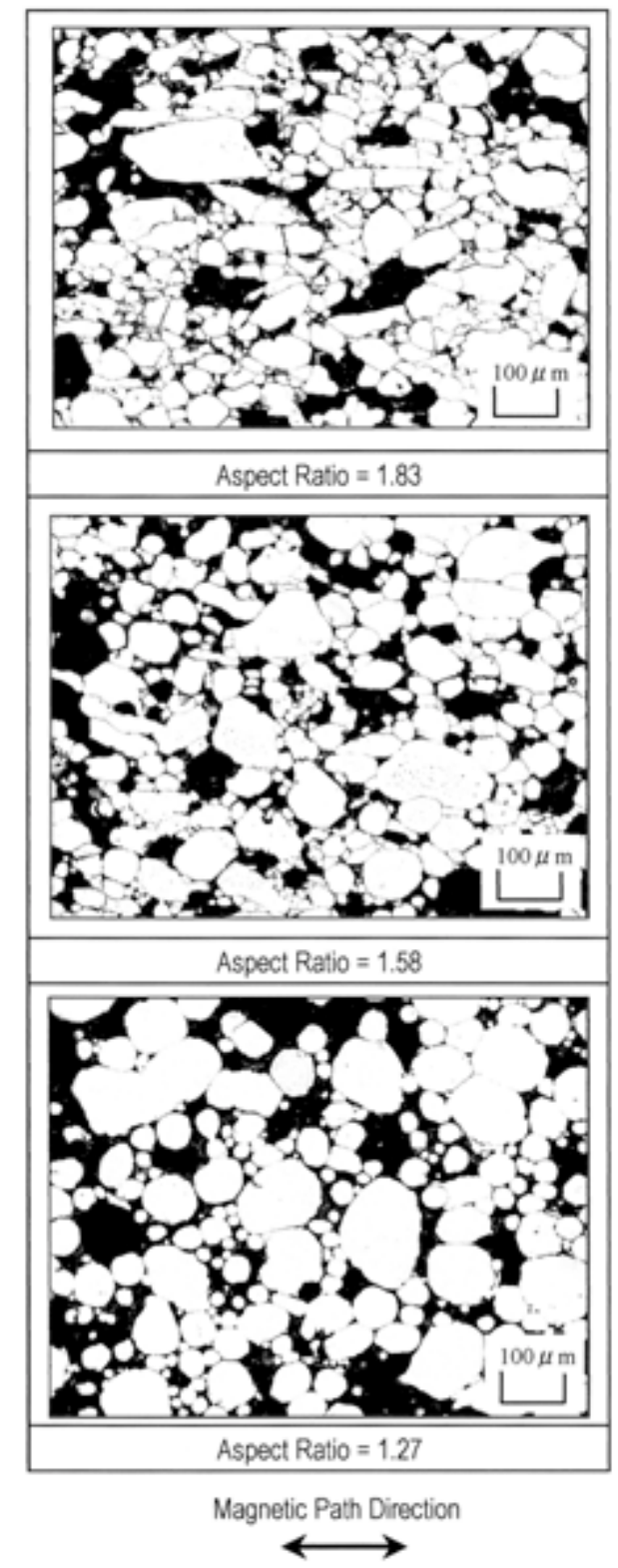

Fig.1. Microstructures of compressed cores with modified-water atomized powders.

された磁芯を $\mathrm{Ar}$ 雰囲気中で熱処理した . 磁芯の熱処理は 
$973 \mathrm{~K}$ で保持時間は $3.6 \mathrm{ks}(1$ 時間 ) とした .

\section{4 磁気特性評価}

磁気特性として初透磁率および直流重畳特性を測定し た . LCR メーター (アジレント・テクノロジー製 4284A) を用いて ,0〜8000 A/m までの直流バイアス磁界に $0.4 \mathrm{~A} /$ $\mathrm{m}$ の振幅で周波数 $20 \mathrm{kHz}$ の交流磁界を重畳させ透磁率を 測定した。

\section{3.結果および考察}

\section{1 初透磁率に及ぼす粉末粒子形状の影響}

Fig.2 にアスペクト比および圧粉磁芯の相対密度を変化 させたときの初透磁率の変化を示す .アスペクト比が大き くなる，つまり粒子形状が長円形になるに従い初透磁率は 高くなる．また, 同じアスペクト比でみると, 相対密度が 高いほど初透磁率は高くなっている.圧粉磁芯の相対密度 はプレス成形圧力を変化させることにより変化させた .す なわち, 初透磁率は圧粉磁芯の相対密度だけでなく, 粉末 粒子形状によっても影響を受けることが分かる．

そこで，Fig.2 に示したデータを用いて，初透磁率に及 ぼす粉末のアスペクト比と圧粉磁芯の相対密度の影響に ついて重回帰分析を行い，以下の式を得た．

$$
\begin{aligned}
& \mu^{\prime}=79.4 n+510 \eta-450.5 \\
& \text { ここで, } \\
& \mu^{\prime}: \text { 初透磁率 } \quad n: \text { 粉末粒子のアスペクト比 } \\
& \eta \quad: \text { 圧粉磁芯の相対密度 }
\end{aligned}
$$

計算された重相関係数は 0.97 と高い相関を示し，初透 磁率は粉末のアスペクト比と圧粉磁芯の相対密度の両方

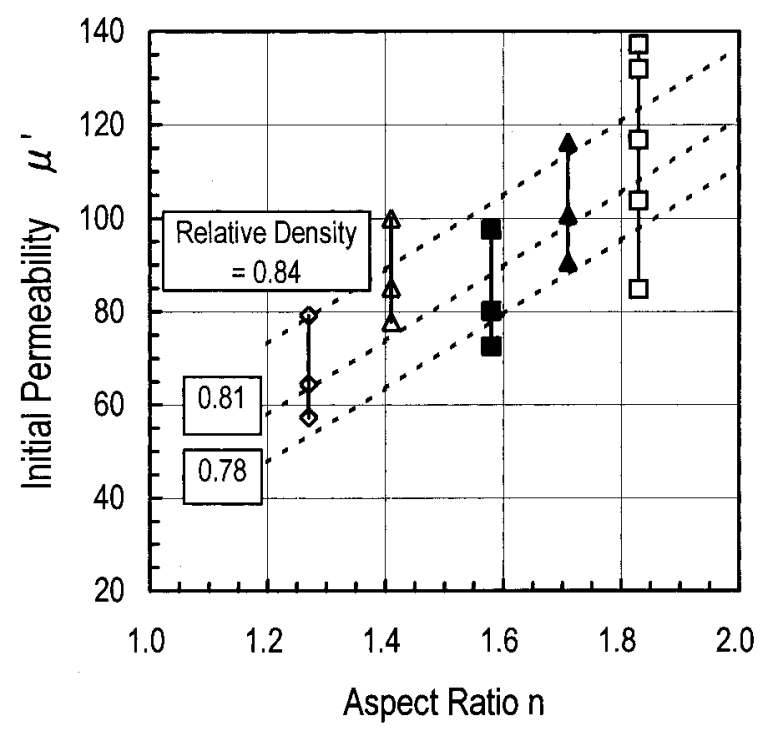

Fig.2. Relationship between initial permeability $\mu^{\prime}$ and aspect ratio of particles. Dotted lines show calculated permeability using equation (1).
に強く影響されることが分かる.Fig.2 の破線は得られた 回帰式 (1) 式を用いて計算した計算値を示している . 測定 值と計算值とは全体的によく一致していることがわかる． 次に初透磁率に及ぼす粉末のアスペクト比と圧粉磁芯 の相対密度について, 圧粉磁芯の見掛けの有効反磁界係数 の考え方を取り入れ更に詳しく検討を行った．Ollendorf ${ }^{3)}$ によれば,見掛けの有効反磁界係数を用いて透磁率を表現 すると

$\mu^{\prime}=\eta\left(\mu_{t}-1\right) /\left[N(1-\eta)\left(\mu_{t}-1\right)+1\right]+1$

で与えられる .

ここで,

$\eta$ : 圧粉磁芯の相対密度 $\eta=d /\left(7.1 \times 10^{3}\right)$

$d:$ 密度 $\left(\mathrm{kg} / \mathrm{m}^{3}\right) \quad 7.1 \times 10^{3}:$ 本合金の真密度 $\left(\mathrm{kg} / \mathrm{m}^{3}\right)$

$\mu_{t}$ : 真の透磁率 $\quad N$ : 圧粉磁芯の有効反磁界係数

である.$\mu_{t}$ の值は相対密度が 1 となったときの透磁率に 相当する .ここでの計算では，以下に述べる Fig.3 に示し たデータを相対密度 1 まで放物線で外挿した值である 1000 を用いた。

Fig.3に初透磁率に及ぼす圧粉磁芯の相対密度と粉末粒 子のアスペクト比の影響を示す.実線は測定值であり, 破 線は (2) 式を用いた計算值を示している .この計算では有 効反磁界係数 $N$ をパラメータとして変化させている .

実測値と (2) 式から計算された計算値との比較から粉末 粒子のアスペクト比が大きいほど有効反磁界係数 $N$ が小 さくなっており，光れに従い初透磁率が大きくなっている

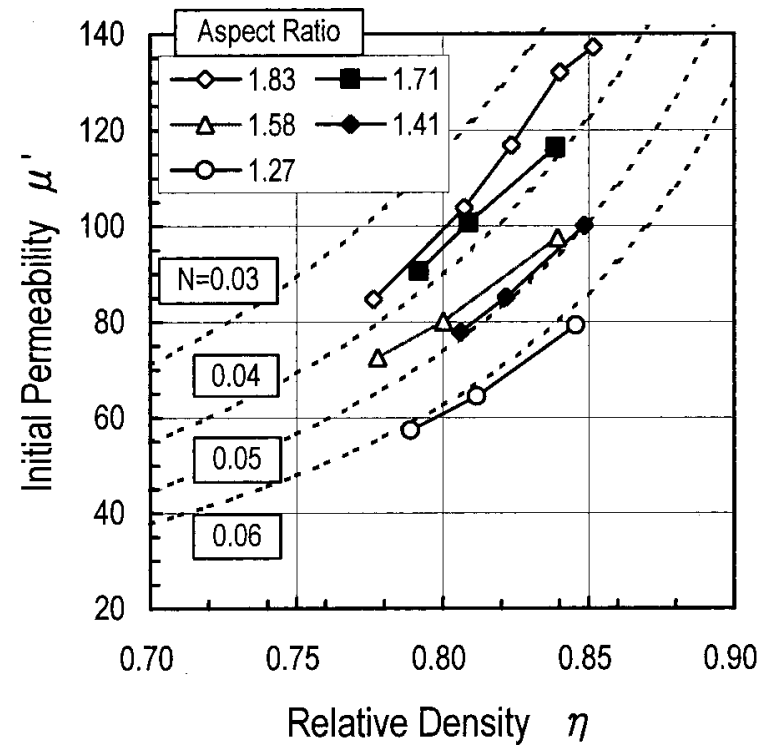

Fig.3. Relationship between initial permeability and relative density of cores with various aspect ratio of particles. Dotted lines show calculated permeability using equation (2) with various demagnetizing factors $N$. 
Table 3. Effective demagnetizing factors calculated by equation(2) and (3).

\begin{tabular}{c|c|c|c|c}
\hline A & B & C & D & E \\
\hline $\begin{array}{c}\text { Aspect Ratio } \\
\text { of Particle } \\
n\end{array}$ & $\begin{array}{c}\text { Effective Demagnetizing } \\
\text { Factor calculated by (2) }\end{array}$ & $\begin{array}{c}\text { Demagnetizing Factor } \\
\text { calculated by (3) } \\
N^{\prime}\end{array}$ & $\begin{array}{c}\text { Aspect Ratio } \\
\text { calculated by (3) }\end{array}$ & $n^{\prime}$ \\
\hline 1.27 & 0.061 & 0.27 & 4.69 & 3.69 \\
\hline 1.41 & 0.049 & 0.25 & 5.49 & 3.89 \\
\hline 1.58 & 0.045 & 0.22 & 5.84 & 3.70 \\
\hline 1.71 & 0.039 & 0.20 & 6.44 & 3.77 \\
\hline 1.83 & 0.035 & 0.19 & 6.94 & \\
\hline
\end{tabular}

ことがわかる.また圧粉磁芯の相対密度が増加すると実測 值と同樣に (2) 式で計算される初透磁率も増加している。 初透磁率の増加の傾向は計算值と実測値はほぼ一致して おり,粉末のアスペクト比が同じなら圧粉磁芯の相対密度 か変化しても有効反磁界係数はほぼ一定であると考えら

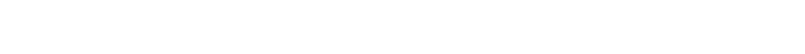
磁界係数を計算した結果をTable 3 のB 欄に示す.

以上の議論から粉末粒子形状により初透磁率が変化す るのは,圧粉磁芯の有効反磁界係数か変化することが产の 物理的な理由であることか確かめられた.続いて，粒子の アスペクト比と有効反磁界係数との関係について議論を 進める.回転楕円体の磁性体が他の磁性体との相互作用が なく孤立して存在する場合には，反磁界係数は (3) 式で表 されることが知られている ${ }^{4)}$.

$$
\begin{gathered}
N^{\prime}=1 /\left(n^{2}-1\right) \cdot\left\{\left[n /\left(n^{2}-1\right)^{1 / 2}\right] \cdot\left[\ln \left(n+\left(n^{2}-1\right)^{1 / 2}\right)-1\right]\right\} \quad \cdots(3) \\
n: \text { 粉末のアスペクト比 } \quad N^{\prime}: \text { 粉末の反磁界係数 }
\end{gathered}
$$

(3) 式から弚れ光れのアスペクト比の粉末で反磁界係数 $N^{\prime}$ を計算した結果を Table 3 のC欄に示す . (2) 式から計 算された有効反磁界係数 $N$ (B 欄) と(3) 式から計算され た反磁界係数 N' (C 欄) の結果を比較すると, $N^{\prime}$ の方が かなり大きな值を示し，大きく異なっている．この理由 は, (3) 式の $N^{\prime}$ は磁性体が周囲の磁性体との相互作用が なく，独立した状態での反磁界係数を表しているのに対 し，現実の圧粉磁芯では粉末粒子が非常に接近して存在す るため，何個かの粒子が見掛け上磁気的に繋がった状態と なり B $\mathrm{B}$ 闌の有効反磁界係数 $N$ は大きく低下しているもの と考えられる

弚こで，(3) 式を用い，逆にB 欄の $N$ となるようなアス ペクト比 $n^{\prime}$ を求めた結果を $\mathrm{D}$ 欄に示す.個々の粉末粒子 は $1.3 \sim 1.8$ のアスペクト比をもっているが, 弚れを成形 した圧粉磁芯では, 磁気的には見掛け上アスペクト比が $4.7 \sim 6.9$ 程度の連続した粒子の集合体として振る舞って いるものと考えられる $\mathrm{E}$ 欄には $\mathrm{A}$ 欄の実際の粉末のアス ペクト比である $n$ と D欄の (3) 式から求めた見掛け上のア
スペクト比の比率を示してある.この值は,いずれの圧粉 磁芯でも，平均的に約 4 個の粒子が連続して繋がった状態 て磁化していることを意味している この推定を直接実証 するようなデータは今のところないが,今後の課題とした い.

\section{2 直流重畳特性に及ぼす粉末粒子形状 の影響}

次に直流重畳特性の粉末粒子形状依存性について議論 する . スイッチング電源や DC-DC コンバーターの特性を 決める上で, 弚れらに使用される圧粉磁芯の直流重畳特性 は重要なファクターである．つまり，例えば DC-DC コン バーターのチョークコイルに大きな直流電流と交番電流 とが重畳して流れる場合, 弚の圧粉磁芯には直流磁界下で 大きな透磁率が要求される.

Fig.4に粉末粒子のアスペクト比を変化させた時の直流 重畳特性を示す .この图ではプレス成形圧力をコントロー ルし圧粉磁芯の相対密度を変化させることにより,すべて の圧粉磁芯の初透磁率を約 100 に調整した.測定を行った すべての直流磁界においてアスペクト比の小さい粉末ほ ど高い透磁率を示し,直流磁界が大きくなっても透磁率の 低下は小さい.初透磁率が同じなら , アスペクト比の小さ い粉末を用いた方が高い重畳特性を示すことが分かる.

次に, 種々のアスペクト比をもつ圧粉磁芯で, 弚の相対 密度を約 0.84 とほぼ一定としたときの直流重畳特性を Fig.5 に示す. アスペクト比の大きな長円形状の粉末を用 いた圧粉磁芯の場合, 初透磁率は高いものの直流磁界が大 きくなるに従い透磁率は急激に低下する．弚れに対して， アスペクト比の小さい球形状の粉末を用いた圧粉磁芯の 場合, 初透磁率は比較的低いものの直流磁界が大きくなっ ても透磁率の低下は小さい . 直流磁界が $3000 \mathrm{~A} / \mathrm{m}$ 以下の 範囲ではアスペクト比の大きな粉末を用いた方が透磁率 が高く, 逆に $3000 \mathrm{~A} / \mathrm{m}$ 以上の直流磁界ではアスペクト比 の小さい粉末を用いるほど透磁率が高くなっている. 


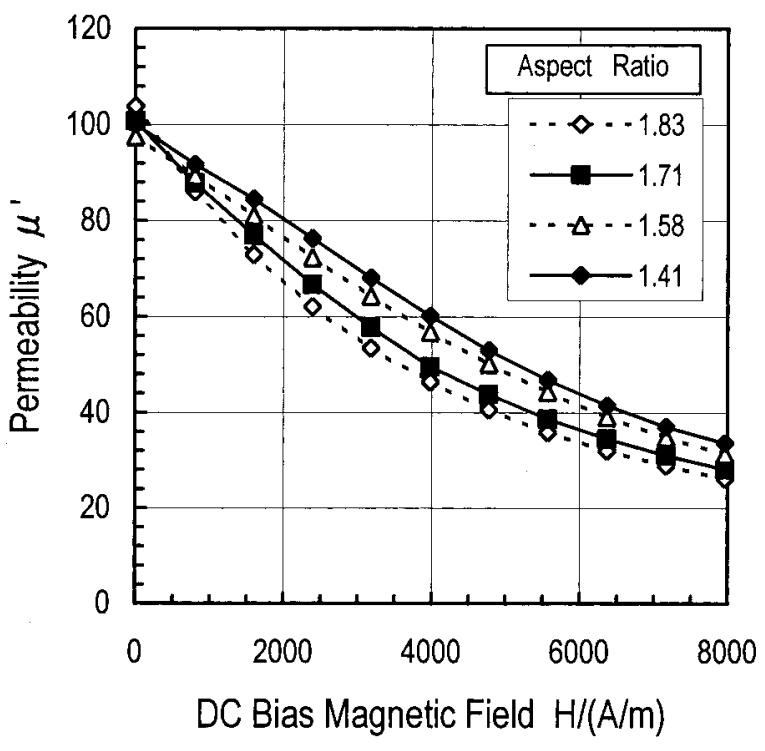

Fig.4. DC bias characteristics of permeability. Initial permeability of every core is around $\mu_{i}=100$.

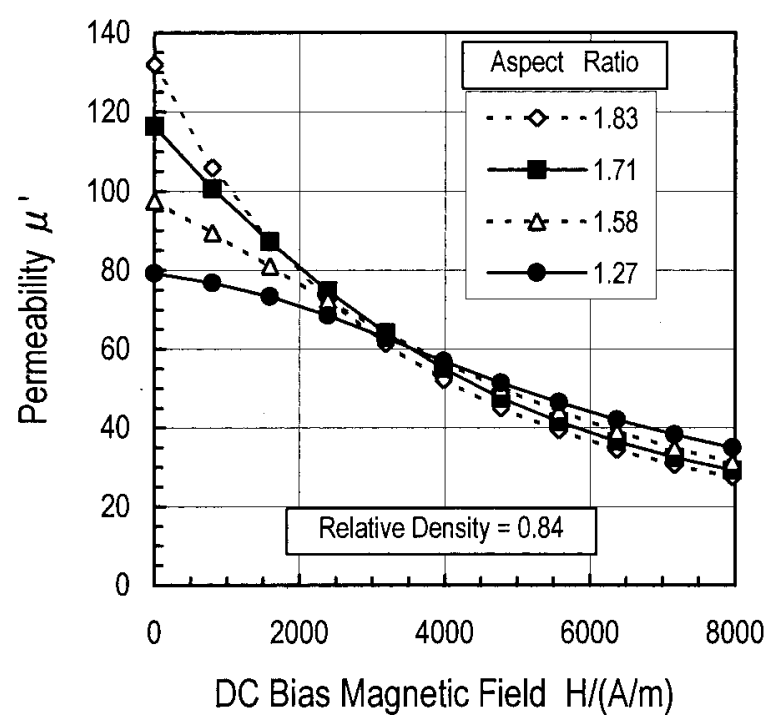

Fig.5. DC bias characteristics of permeability. Relative density of every core is around 0.84 .

そこで次に直流磁界が $800 \mathrm{~A} / \mathrm{m}$ および $6400 \mathrm{~A} / \mathrm{m}$ のとき の透磁率と初透磁率の関係を光れ光れ Fig.6 および Fig.7 に示す.図中の破線は同じ圧粉磁芯の相対密度を示してい る. $800 \mathrm{~A} / \mathrm{m}$ と比較的小さい直流磁界の場合は, 粉末のア スペクト比および圧粉磁芯の相対密度が増加するにつれ 透磁率は増加している。弚れに対し, 直流磁界が $6400 \mathrm{~A} /$ $\mathrm{m}$ の場合は, 圧粉磁芯の相対密度は高い方がよいが,粉末 のアスペクト比は逆に小さい方が透磁率は高くなってい る、つまり, 低磁界バイアス下で高い透磁率を得るために

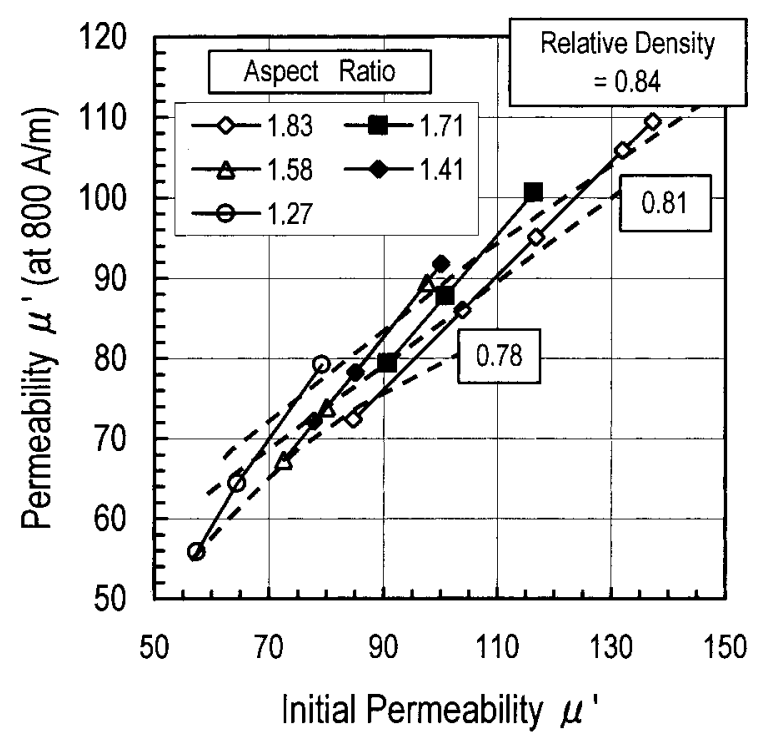

Fig.6. Relationship between initial permeability and permeability at $\mathrm{DC}$ bias $800 \mathrm{~A} / \mathrm{m}$.

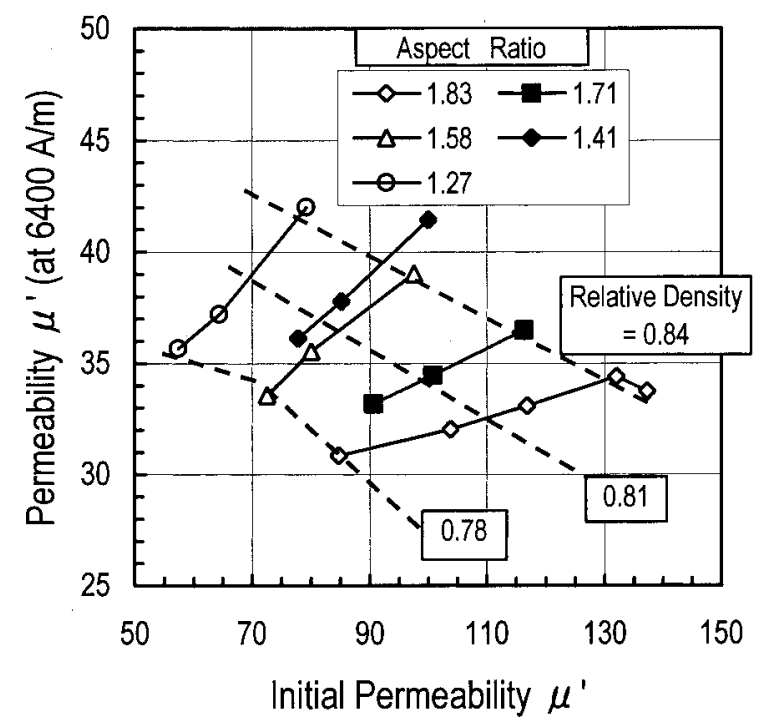

Fig.7. Relationship between initial permeability and permeability at $\mathrm{DC}$ bias $6400 \mathrm{~A} / \mathrm{m}$.

は圧粉磁芯の相対密度を高め,粉末のアスペクト比も大き くして初透磁率を高くした方が良く，一方，高磁界で高い 重畳特性を得るためには圧粉磁芯の相対密度を高め, 粉末 のアスペクト比は小さくして初透磁率を低下させた方が 良いと考えられる.以上の結果より, スイッチング電源や DC-DC コンバーターのチョークコイル等に使用する場合 には, 弚の電流条件を十分考慮して, 圧粉磁芯の種類 (粉 末の形状, 圧粉磁芯の密度 ) を選択することが重要と考え られる。 


\section{4 . 結 論}

本報告ではFe-Si-Al系合金で改良型水噴霧法によって粒 子形状を連続的に变化させた 5 種類の粉末を用いて圧粉磁 芯を作製し，透磁率と光の直流バイアス磁界依存性 (直流 重畳特性) を評価した。乥こで以下の結論を得た。

(1) 初透磁率は粉末粒子のアスペクト比と圧粉磁芯の相対

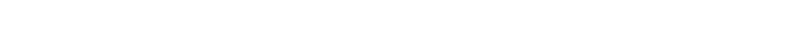
る。

(2) Ollendorf の式を用いた解析から，アスペクト比が大き くなると初透磁率が高くなる原因は, 圧粉磁芯の見掛けの 有効反磁界係数が小さなるためと考えられる .

(3) 圧粉磁芯においては, 平均 4 個程度の粉末粒子か磁気 的に連続した状態で磁化していると推定される.

(4) 同樣に直流重畳特性も粉末粒子のアスペクト比と圧粉 磁芯の相対密度に影響を受ける。

(5) 低磁界の直流バイアス下では圧粉磁芯の相対密度およ び粉末粒子のアスペクト比が大きいほど透磁率が高くな る.一方, 高磁界の直流バイアス下では圧粉磁芯の相対密 度が高く粉末粒子のアスペクト比が小さいほど透磁率は 高くなる .

\section{謝 辞}

本研究を遂行するに当たり，一連の実験の実施に協力し ていただいた大同特殊鋼妹技術開発研究所管理室試作第 三係の坂元親男氏に感謝します．また最後になりました が,原料粉として各種噴霧粉を提供して頂きました大同特 殊鋼姝粉末事業部の方々にお礼を申し上げます．

(文献)

1)斉藤貴伸，矢萩慎一郎: 電気製鋼, 69(1998), 181.

2)斉藤貴伸 武本聡: 電気製鋼, 71 (2000), 287.

3)高城重彰，清田禎公:粉体および粉末冶金, 32(1985), 259.

4)太田恵造: 磁気工学の基礎I,(1973), p.38 [共立出版] . 